\title{
Informationsteknologi i folkebibliotekerne - de første ti år
}

\author{
Anmeldt af Lise Drewes Nielsen
}

Pierre Evald: Informationsteknologi i folkebibliotekerne - de ti forste år. Biblioteksarbejdes skriftserie nr. 11.140 sider.

Pierre Evald: Informationsteknologi i danske folkebiblioteker. Diskette.

Pierre Evald: Informationsteknologi i danske folkebiblioteker - systemfaser, status og perspektiver. Bind 1: Rapport. Bind 2: Bilag. Danmarks Biblioteksskole, Aalborgafdelingen. Ialt 572 sider.

Rapporterne er den første samlede beskrivelse af, hvorledes de danske folkebiblioteker har udviklet sig med informationsteknologien. Rapporterne er resultatet af en større undersøgelse af ti danske folkebiblioteker, der kan betegnes som avantgarde inden for ITområdet, de danske spydspidsbiblioteker på området. Det er bibliotekerne i : Bjerringbro, Silkeborg, Blåbjerg-Blåvandshuk-Varde, Herning, Egvad, Nordborg, Vissenbjerg-Tommerup, Korsør, Ølstykke, Ballerup. Nogle af dem har desuden været forsøgsbiblioteker for udvikling af IT.
Undersøgelsens metode er baseret på en større spørgeskemaundersøgelse blandt de ansatte på bibliotekerne. Ialt 330 besvarelser og en flot svarprocent på $94.6 \%$. Der er desuden foretaget interviews med nøglepersoner på bibliotekerne, med ledelsen og med udvalgte nøglepersoner fra Danmark og Norden. Undersøgelsen er således funderet på et omfattende datamateriale.

I 20 kapitler beskrives og analyseres udviklingen på området. I kap 5-11 beskrives hvorledes udviklingen inden for bibliotekerne har været, lige fra systemudvikling, implementering og personalesammensætning. Der gives en grundig beskrivelse af sektorens udvikling over tiåret.

Der er stor variation i de enkelte bibliotekers brug af systemer og der er variation i vurderingerne af processen. I implementeringen af systemerne mener således to ud af tre ansatte at de har haft megen stotte fra kollegaer, men hver tredje ansatte mener at lederne ikke har været i stand til at yde den fornødne støtte i den krævende omstillingsproces. Der er dog helt overve- 
jende positive holdninger til bibliotekets procestilrettelæggelse af implementeringen. Fordelt efter faggrupper er bibliotekareme imidlertid de mest forbeholde.

I kap 12-15 analyseres hvad omstillingen har betydet for jobindhold, arbejdsmiljø, kvalifikationer og organisation.

Jeg vil specielt kommentere de to første. Denne del af undersøgelsen har haft min store interesse, fordi jeg var med til at udarbejde diverse konsekvensunders $\varnothing-$ gelser $\mathrm{i}$ begyndelsen af 80erne, med det formål at forsøge at vurdere hvorledes implementeringen af edb (som det hed dengang) kunne formes, og hvorledes de uønskede konsekvenser kunne undgås.

Denne undersøgelse søger konsekvent at sammenholde resultaterne her ti år efter med antagelserne fra dengang. Og udviklingen bevæger sig selvfølgelig ikke entydigt $i$ de retninger, som undersøgelseme for ti år antydede. Denne undersøgelse viser således: at edb for ca. 1/3 har betydet en større jobtilfredshed (lavest for bibliotekarer), mens det for en anden 1/3 ikke har haft den store indflydelse. Altså et broget billede. Hvad variation $i$ arbejdet angår, angiver langt den overvejende del at edb har betydet stor variation i arbejdet, forstået som mere varierede arbejdsopgaver. Endvidere har edb tilsyneladende næsten ingen indflydelse haft på en tættere brugerkontakt.

Der er i undersøgelsen mange af den type resultater. Det er svært at sammenfatte en entydig retning på konsekvenserne. Det er også svært at vurdere, hvorfor det ikke gik som de ti år gamle konsekvensundersøgelser forsøgte at forudse. Her kunne det have været interessant, at vurdere, hvad den omfattende aktivitet omkring de gamle konsekvensundersøgelser, egentlig har betydet. Der blev f.eks. lagt stor vægt pả, hvor vigtigt det var at fastholde den store variation i biblioteksarbejdet. Har det haft indflydelse på resultaterne i dag?

Sådanne svar kunne måske gives i den efterfølgende debat af denne undersøgelse. Den egner sig nemlig fortrinligt som udgangspunkt for den videre debat $i$ spydsspidsbibliotekerne, såvel som i alle andre biblioteker.

Jeg vil imidlertid godt advare lidt mod at trække for hurtige konklusioner på en sammenstilling af de tidligere undersøgelser (konsekvensundersøgelserne) og denne analyse. Konsekvensundersøgelserne var karakteriseret ved udelukkende kvalitative metoder, dvs. baseret på intensive personlige interviews. Denne undersøgelse er omvendt baseret på kvantitativ metode med spørgeskemaer. Der er store metodiske vanskeligheder med at sammenligne to forskellige analysemetoder.

Desuden synes jeg at der kan være vanskeligheder med at tolke en spørgeskemaundersøgelse. Det gælder ikke denne undersøgelse specifikt, men mere generelt. I denne undersøgelse er jobtilfredshed undersøgt ved spørgsmålet: Hvad har edb betydet for din tilfredshed med dit job? Det kan da være vanskeligt at svare entydigt på. Og vanskeligt at tolke resultaterne. Undersøgelsen kan imidlertid angive nogle retninger for udviklingen på bibliotekerne. Den kan beskrive nogle overordnede træk, men den har sværere ved at forklare hvorfor IT-implementeringen har udviklet sig som den har.

I kapitlet om arbejdsmiljø viser resultaterne et entydigt og noget bekymrende billede. Der er stresspåvirkninger $i$ arbejdet med edb og der er gener ved skærmarbejde. Således sammenfatter undersøgelsen, at $84 \%$ af det samlede personale i varieret omfang har oplevet stress ved systemnedbræk og at $80 \%$ har oplevet det i forbindelse med ventetid. Desuden har $40 \%$ generende træthed i nakke skuldre, hovedpine og øjenbesvær. Der ligger $\mathrm{i}$ undersøgelsen nogle massive advarsler på arbejdsmiljøområdet. Det er advarsler, der også findes inden for andre arbejdsområder, hvor edb teknologien tages i anvendelse. De nye nedslidningsområder er edbarbejdet. Bibliotekerne har imidlertid, hvad konsekvensundersøgelserne for ti år siden og hvad denne undersøgelse også har vist, ry for at være arbejdspladser, der lægger vægt på et godt fysisk og psykisk arbejdsmiljø. Derfor er der store muligheder for at påvirke arbejdsmiljøet $i$ en god retning på baggnund af denne undersøgelses resultater. 
De sidste kapitler 16-20 handler om profil, opgaveudvikling, informationspolitik og økonomi. Det afsluttende kapitel giver en perspektivering og udpeger strategiske variable. Undersøgelsen viser generelt, at der er sket meget på edb-området på de ti biblioteker. Bibliotekerne har ændret arbejdsgange og profil med IT. Imidlertid er opgaven ikke afsluttet. Der er stadig store problemer med arbejdsmiljøet og nye udfordringer vedrørende den fremtidige organisationsudvikling f.eks. faggrænseændringer, nye organisationsformer med f.eks. gruppearbejde mv.

Det er en grundig veldokumenteret analyse, med mange gode relevante referencer. Den trækker nogle historiske linier op i bibliotekernes udvikling med IT, samtidig med at den skuer fremover mod udfordringerne. Den er et godt grundlag for den videre debat, og for de biblioteker, der har implementeringen foran sig. 